\title{
日本人の皮下脂肪厚の記述疫学的研究
}

\author{
矢ヶ崎信子* 豊川 裕之**
}

\section{The Frequency of Subcutaneous Fat Thickness of the Japanese by Sex and Age}

\section{Nobuko YAGASAKI* and Hiroyuki TOYOKAWA**}

The subcutaneous fat thickness was investigated to obtain the general characteristics of Japanese fat distribution by sex and age. Our subjects consist of 1,477 males and 1,933 females of all age groups in various localities in Japan. The newly developed A-mode type ultrasonic instrument was utilized to measure fat thickness including such locations as biceps, triceps, subscapula, suprailiac, thigh anterior, thigh posterior, and calf. The data obtained were analyzed by mean, standard deviation, and percentile. Our findings are summarized as follows:

1) It is confirmed that the subcutaneous fat layer of females is thicker than that of males.

2) Examining the ratio of upper-arm and trunk in subcutaneous fat layer, i.e. (biceps + triceps)/(subscapula + suprailiac), the adults' ratios are smaller than those of infants, and adult males accumulate more fat abdominally than adult females do.

3) The percentiles we obtained will provide the criteria for subcutaneous fat thickness of the Japanese by sex and age.

\section{I は じめに}

超音波を利用した計測専用機（A モード式超音 波皮脂厚計）を用いて，日本人の皮下脂肪厚（以 後, 皮脂厚とする) を測定し，性・年路・部位別 の代表値を観察した。従来, 皮脂厚は各種の skinfold caliper で計測されてきたが, その精度は皮層 を挟む (skinfold) 手技に起因する計測上の限界を 乗り越えることができなかった。しかし，肥満が 成人病との関連で先進国に注目され，また，るい そうが, 飢えや小児栄養失調との関連で開発途上
国で注目されるよらになったので，精度の高い皮 脂厚計の開発が必要となり, その皮脂厚の正常域 と異常域の判定が望まれている。このような要望 を受け，超音波技術の進歩とともに，超音波を用 いて皮脂厚を測定する試みが行われている。

皮脂厚は，在来の皮脂厚計を用いた報告では， 上腕後部, 肩甲骨下角部などの限られた部位の計 測しか行われていないが，11歳・12歳頃から上腕 部の皮脂厚に性差が顕著になる。つまり, 女性は 増加し, 男性は減少すると言われている（Johnston et al，1974）。 また，男女とも成人期におい

* 女子栄養大学栄養学部臨床栄養学研究室

** 東邦大学医学部公衆衛生学教室

* Department of Clinical Nutrition, Faculty of Nutrition, Kagawa Nutrition College

** Department of Public Health, Toho University School of Medicine 
ては体幹（肩甲骨下角部と腸骨稜上部）に皮下脂 肪の沈着が進む傾向があり，かつ，肩甲骨下角部 は男女とも40歳代を最大として以後減少傾向を示 すと言われている(厚生省，1985)。 また，成人女 性の皮下脂肪の分布状況には体幹の皮下脂肪が多 い男性型と，逆に四肢に多めに分布する女性型と に分けられるとも報告されている(Ashwell et al, 1978). 本論文は, $\mathrm{A}$ モード式超音波皮脂厚計を用 いて性・部位・年齢別に皮脂厚の代表值を求める とともに，在来の skinfold caliper を用いた上述 の知見についても観察した.

\section{II 対象と調査地区・期間}

対象人数は表 1 に示されている。男性は新生児 から95歳までの 1,477 人, 女性が新生児から 88 歳ま での 1,933 人で，男女あわせて 3,410 人である．年 齢構成については，新生児および乳幼児期・青少 年期に関しては新生児， $3 ， 4,5 ， 6 ， 7,12$, 15，19歳と各年齢別にまとめ，成年期については， 10 歳きざみに 70 歳以上までの 6 年代にまとめた。 但し，15歳は男性のみであり，19歳は女性のみで ある、また，本研究における新生児とは生後 24 時 間以内の新生児に限定している（今井・豊川,

表 1 対象者の年齢構成及び人数

\begin{tabular}{rrrr}
\hline $\begin{array}{c}\text { 年 齢 } \\
\text { (歳) }\end{array}$ & $\begin{array}{c}\text { 男 } \\
(\text { 人) }\end{array}$ & $\begin{array}{c}\text { 女性 } \\
(\text { 人) }\end{array}$ & $\begin{array}{c}\text { 合 } \\
(\text { 人) }\end{array}$ \\
\hline 新生监 & 83 & 88 & 171 \\
3 & 19 & 20 & 39 \\
4 & 103 & 71 & 174 \\
5 & 114 & 101 & 215 \\
6 & 27 & 21 & 48 \\
7 & 61 & 58 & 119 \\
12 & 73 & 83 & 156 \\
15 & 59 & 0 & 59 \\
19 & 0 & 27 & 27 \\
$20 \sim 29$ & 24 & 91 & 115 \\
$30 \sim 39$ & 126 & 288 & 414 \\
$40 \sim 49$ & 230 & 365 & 595 \\
$50 \sim 59$ & 229 & 358 & 587 \\
$60 \sim 69$ & 177 & 231 & 408 \\
70 歳以上 & 152 & 131 & 283 \\
\hline 合 計 & 1477 & 1933 & 3410 \\
\hline
\end{tabular}

1987）. 調査地区は，系統的に選定されたわけでは なく，できる限り日本全国にわたって標本抽出す ることを図って，調査をする機会を与えられたと ころには必ず出向いて計測することに努めたが， 本調査期間では秋田県, 富山県, 群馬県, 千葉県, 東京都, 神奈川県, 静岡県, 岐阜県, 大分県の 9 地区にとどまった。しかし，地区としては大都市， 地方都市, 農村, 農山村を含んでいる。な拉, 新 生児については東京大学医学部附属病院産婦人科 に怙いて計測したものであり，3 歳から15歳は東 京都内に括ける幼稚園拈よび学校施設の健康診断 受診者, 19歳の女性は某地方大学の学生である. 20 歳以上の成人男女は，保健所などの地域や事業 所で実施された集団検診の受診者と東京大学医学 部附属病院に通院する外来患者であり，その割合 は, 事業所の成人病検診受診者が578人 ( $24.1 \%)$, 地域に打ける集団検診の受診者が 1,666 人 (69.4\%)，病院外来患者が158人 (6.5\%) である。 いずれの場合も多人数を短時間で測定しなければ ならないといら制約があり，集団検診時の制約(時 間，空間および人手等の制限）の厳しさに応じて 計測項目を適宜削減させてのデータ収集であった ため, 標本数は計測部位によって不揃いとなった。 このような標本の性質を考慮して, 対象者の地域 特性や職業特性などの要因については触れずに一 括して集計した。調查期間は1983年 4 月から1986 年 7 月である.

\section{III 計測項目および計測方法}

1. 身長拉よび体重

対象者の皮脂厚を計測するとともに，身長，体 重の二項目を測定した。

2. 皮脂厚の計測部位

皮脂厚の計測部位はすべて左側であり，厚木 （1933）や東（1954）が用いた Erdheim の格子線を 参考に, 左右あわせて18体部位を実際に検討し(豊 川ほか, 1984a), このうち Keys・Brožek (1953) やKatch (1983) が採用している部位を含めた 7 部位（図 1）を次のように選定した。

上肢は以下の 2 点とする. 


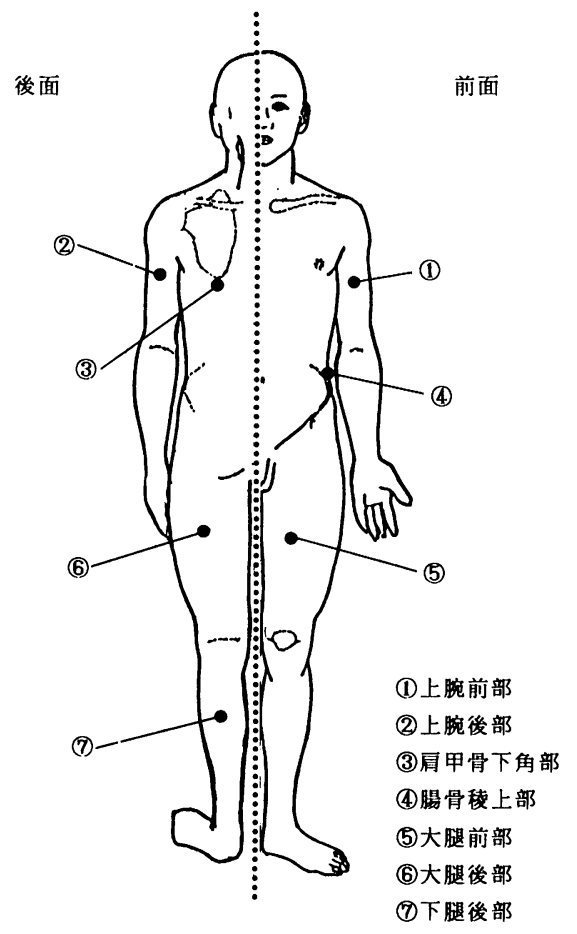

図 1 計測部位（左側）

(1) 上腕前部：肩峰点と肘蓇との中点。

(2) 上腕後部：肩峰点と肘頭との中点。 体幹は以下の 2 点とする。

(3) 肩甲骨下角部：肩甲骨下角の下端より垂直2 $\mathrm{cm}$ 下.

(4) 腸骨稜上部：腋窩中線と腸骨稜上部から近 位 $2 \mathrm{~cm}$ との交点.

下肢は以下の 3 点とする.

(5) 大腿前部：上前腸骨棘点と膝蓋骨下端との 中点.

(6) 大腿後部：大腿前部計測点の水平交らしろ.

(7) 下腿後部：膝窩と踵点との近位 3 分の 1 .

対象者の姿勢は，上腕前部および腸骨稜上部を 計測する時は肘を完全に伸展させて手掌を前面に さけた解剖学的立位で，その他の計測部位の時は 手掌を体側にむけて腕を下に垂らした自然立位の 状態（和才・嶋田，1975）にさせて計測した。

3. 皮脂厚の計測方法

皮脂厚の計測に際しては，A ード式超音波皮
脂厚計のTATT TH-500を用いた。探触子 （probe）の皮膚接触面にゼリー（心電図用伝導ゲ ル）を塗布し，計測部位に探触子をあてると，探 触子より送信されるパルスが生体組織間の音響イ ンピーダンス（密度×音波）の異なる脂肪と筋組 織との境界面から反射され，再び同一探触子に受 信され，反射波信号を増幅，検波し，その波形を ブラウン管面に表示させる。そして，表示された 反射波の中から脂肪と筋肉との境界からの反射波 （これを標的波と呼ぶ，豊川ほか，1984b）を同定 し，体表から筋肉までの距離（音波が往復する時 間× $1 / 2$ を音速で除したもの)を皮脂厚として計測 するものである。つまり，皮䖉の厚さも含む，波 形の読み取りにあたっては，完全自動式のモード I と，精度は高まるがコントローラー操作を行な らために高度の技術を要する半自動式のモード II がある，本研究の計測值はモードIIによるもので ある。な挔，超音波の周波数は $5 \mathrm{MHz}$ (波長0.3 $\mathrm{mm}$ ), 皮下組織中の音波速度は $1540 \mathrm{~m} / \mathrm{sec}$ として 距離に換算している.

\section{IV 検討内容}

1. 対象者の身長, 体重の平均値を全国平均(昭 和59年度学校保健統計調查, 昭和 58 年度国民栄養 調査, 昭和 55 年度乳幼児身体発育調査）と比較を 行ない，標本の偏りについて検討する。

2. 皮脂厚の 7 部位(上腕前部，上腕後部，肩甲 骨下角部, 腸骨稜上部, 大腿前部, 大腿後部, 下 腿後部) のそれぞれについて，性別・年齢別に平 均値と標準偏差を算出し，性差および年齢変化を 観察する.

3. 皮脂厚のうち各年齢ごとの標本数が 50 人以 上の部位，すなわち上腕前部，上腕後部，肩甲骨 下角部，腸骨稜上部については，上肢と体幹との 対比から年齢に伴ら皮下脂肪の沈着傾向を検討す る.

4.さらに, 3 の項目で挙げられた 4 部位のう ち,これまでの skinfold caliper でも計測点とし て最も多く採用されてきた上腕後部，肩甲骨下角 部, 腸管稜上部のパーセンタイル值 $(3,10,25$, 
$50 ， 75 ， 90 ， 97 \%$ ) を求め，性別・年齢別に体部 位ごとの皮脂厚の分布による肥満・るいそうの判 定基準を提示する。

なお，性差の検討に用いた $\mathrm{t}$-検定を含めて，す ベての統計処理は東京大学大型計算機センターの HITAC M200Hを利用した。

$$
\text { V 結 果 }
$$

1. 対象者の身体状況に係わる計測項目, 身長と
体重の平均値と全国平均値との比較

本調査標本の平均值は，昭和55年度乳幼児身体 発育調査(厚生省, 1984), 昭和59年度学校保健統 計調査(文部省, 1984), 昭和58年度国民栄養調査 (厚生省, 1985)の全国平均と比較すると, 身長(図 2 ), 体重 (図 3) いずれについても，7歳の男女 は国民栄養調査と学校保健統計調査のいずれの全 国平均よりも幾分大きく，70歳以上の女性は国民 栄養調査結果よりもわずかに小さいが，他の年代
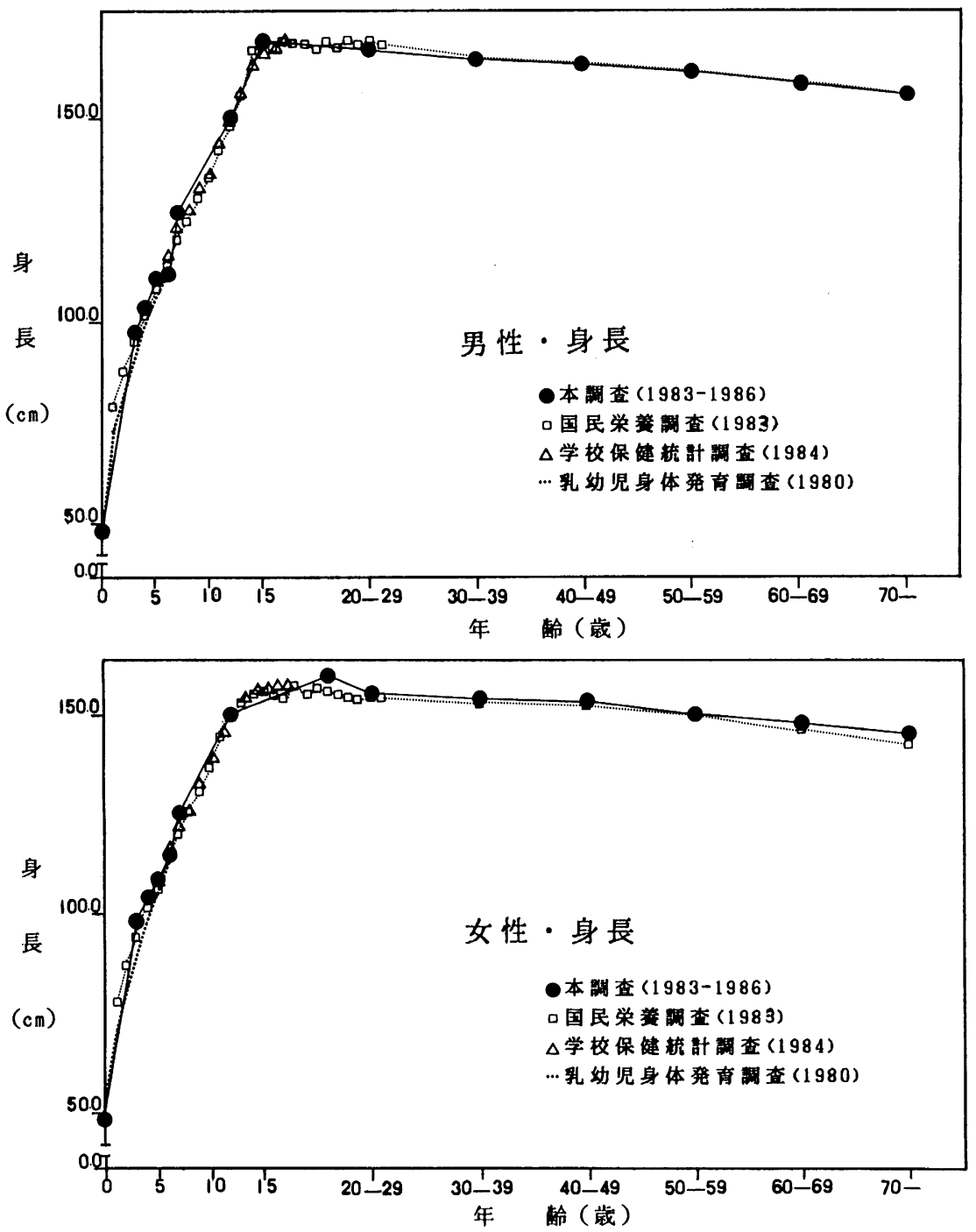

図 2 全国平均との比較（身長） 

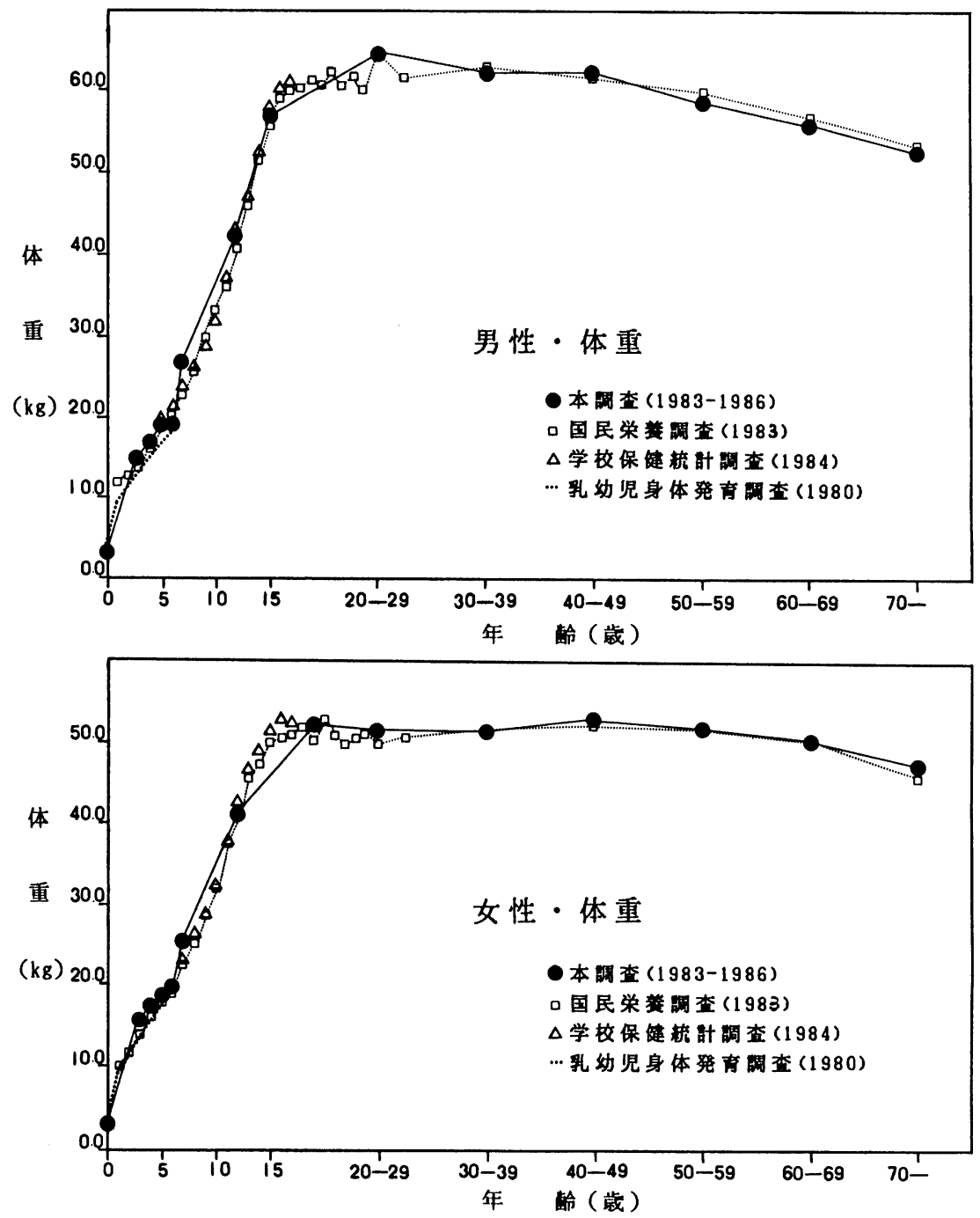

図 3 全国平均との比較（体重）

については大きな格差は見られなかった。また，

身長・体重が男女とも10歳代半ばまでに顕著に増 大するといった，年齢ごとの平均値の系統的な動 きについてはよく一致した。体重は全国平均（国 民栄養調查）では男性が30歳代で女性が40歳代で 最大となるが，本資料では男性が20歳代で女性が 19歳で最大となっている。しかし，表 1 に示され るように，それぞれの年代の対象者数が 24 人と 27 人というように少ないため, 標本数が50人以上の 者だけにしぼって観察すると，男女とも40歳代が
最大值となった。

性差は身長・体重とも12歳までは認められない が，成人男女では明らかとなり（p<0.01），その 差は身長が40歳代, 体重が50歳代で最も大きく なった，以上のことから，本研究の標本がわが国 の平均的体格をあらわすものとして充分と考元ら れる。

2. 各部位における皮脂厚值の性差及び年齢変 化

1）上肢の皮脂厚について 
表 2 上腕前部の皮脂厚值（性別・年齢別）

\begin{tabular}{|c|c|c|c|}
\hline $\begin{array}{l}\text { 年 歯) } \\
\text { (歳) }\end{array}$ & $\begin{array}{c}\text { 男 性 } \\
\text { 平均值士標準偏差 (人数) }\end{array}$ & $\begin{array}{c}\text { 女性 } \\
\text { 平均値士標準偏差(人数) }\end{array}$ & 值 \\
\hline & $\mathrm{mm}$ & $\mathrm{mm}$ & \\
\hline 新生児 & $3.6 \pm 0.7(83)$ & $3.6 \pm 0.5(88)$ & -0.48 \\
\hline 3 & $4.6 \pm 0.7(19)$ & $4.5 \pm 0.9(20)$ & $(0.19)$ \\
\hline 4 & $4.2 \pm 0.9(103)$ & $4.6 \pm 1.0(71)$ & $(-2.67)^{* *}$ \\
\hline 5 & $4.0 \pm 1.0(114)$ & $4.5 \pm 0.9(101)$ & $(-3.85)^{* * *}$ \\
\hline 6 & $3.8 \pm 0.9(27)$ & $4.5 \pm 1.0(21)$ & $(-2.74)^{* *}$ \\
\hline 7 & $4.7 \pm 1.7(61)$ & $6.1 \pm 2.3(58)$ & $-3.66^{* * *}$ \\
\hline 12 & $5.7 \pm 2.5(73)$ & $6.6 \pm 2.2(83)$ & $(-2.36)^{*}$ \\
\hline 15 & $3.8 \pm 1.3(59)$ & $-(-)$ & \\
\hline 19 & $-(-)$ & $4.8 \pm 1.0(26)$ & \\
\hline $20 \sim 29$ & $3.8 \pm 0.9(21)$ & $5.2 \pm 1.4(88)$ & \\
\hline $30 \sim 39$ & $3.6 \pm 1.2(107)$ & $5.5 \pm 1.6(276)$ & $-12.78^{* * *}$ \\
\hline $40 \sim 49$ & $3.8 \pm 1.3(197)$ & $6.1 \pm 2.0(338)$ & $-16.09^{* * *}$ \\
\hline $50 \sim 59$ & $3.4 \pm 1.1(186)$ & $6.2 \pm 2.2(338)$ & $-19.28^{* * *}$ \\
\hline $60 \sim 69$ & $3.4 \pm 1.2(171)$ & $6.2 \pm 2.5(230)$ & $-14.83^{* * *}$ \\
\hline 70歳以上 & $3.5 \pm 1.2(151)$ & $6.0 \pm 2.6(130)$ & $-9.82^{* * *}$ \\
\hline
\end{tabular}

$\mathrm{t}$ 值: ${ }^{*} \mathrm{p}<0.05,{ }^{* *} \mathrm{p}<0.01,{ }^{* * *} \mathrm{p}<0.001, \mathrm{df}(\mathrm{n}-2),($ )内は等分散.

表 3 上腕後部の皮脂厚值（性別・年齢別）

\begin{tabular}{|c|c|c|c|}
\hline $\begin{array}{l}\text { 年 齢 } \\
\text { (歳) }\end{array}$ & $\begin{array}{c}\text { 男 } \\
\text { 平均值士標準偏差 (人数) }\end{array}$ & $\begin{array}{c}\text { 女 } \\
\text { 平均値士標準偏差 (人数) }\end{array}$ & 值 \\
\hline & $\mathrm{mm}$ & $\mathrm{mm}$ & \\
\hline 新生児 & $4.0 \pm 0.7(.83)$ & $4.1 \pm 0.7(88)$ & $(-0.87)$ \\
\hline 3 & $7.5 \pm 1.9(19)$ & $8.1 \pm 1.5(20)$ & $(-1.08)$ \\
\hline 4 & $7.0 \pm 1.3(103)$ & $7.9 \pm 1.6(71)$ & $(-3.95)^{* * *}$ \\
\hline 5 & $6.9 \pm 1.2(114)$ & $8.0 \pm 1.5(101)$ & $-5.90^{* * *}$ \\
\hline 6 & $6.9 \pm 1.3(27)$ & $8.1 \pm 1.6(21)$ & $(-2.93)^{* *}$ \\
\hline 7 & $8.2 \pm 2.0(61)$ & $9.5 \pm 1.9(58)$ & $(-3.71)^{* * *}$ \\
\hline 12 & $10.0 \pm 3.5(73)$ & $10.8 \pm 2.5(83)$ & $(-1.63)$ \\
\hline 15 & $5.9 \pm 1.7(59)$ & $-(-)$ & \\
\hline 19 & $-(-)$ & $10.1 \pm 1.4(27)$ & \\
\hline $20 \sim 29$ & $6.7 \pm 2.0(24)$ & $10.1 \pm 2.6(91)$ & \\
\hline $30 \sim 39$ & $6.2 \pm 1.9(126)$ & $11.7 \pm 2.8(287)$ & $-22.90^{* * *}$ \\
\hline $40 \sim 49$ & $6.5 \pm 2.3(229)$ & $12.1 \pm 2.9(365)$ & $-28.12^{* * *}$ \\
\hline $50 \sim 59$ & $5.9 \pm 1.8(218)$ & $12.2 \pm 3.1(352)$ & $-30.23^{* * *}$ \\
\hline $60 \sim 69$ & $6.1 \pm 1.9(177)$ & $12.3 \pm 3.7(231)$ & $-22.00^{* * *}$ \\
\hline 70歳以上 & $6.3 \pm 2.0(151)$ & $11.6 \pm 3.6(130)$ & $-14.74^{* * *}$ \\
\hline
\end{tabular}

$\mathrm{t}$ 值: $\left.{ }^{*} \mathrm{p}<0.05,{ }^{* *} \mathrm{p}<0.01,{ }^{* * *} \mathrm{p}<0.001, \mathrm{df}(\mathrm{n}-2), （ \quad\right)$ 内は等分散.

上腕前部, 上腕後部の皮脂厚の平均値及び標準 偏差を男女別にまとめたのが表 2 , 表 3 である. いずれの部位も女性の方が男性よりも皮下脂肪が 厚く，上腕後部では新生児の時期で既に女児の方 が男児よりも厚くなっているが，統計分析によっ て明らかな性差が認められたのは 4 歳からであり $(\mathrm{p}<0.01)$, 上腕前部は40歳代で, 上腕後部は50歳 代でその差が最大となった。しかし，12歳児の皮 脂厚の平均值に限ってみると，上腕前部ではわず かに性差 $(\mathrm{p}<0.05)$ がみられながらも，同年齢の 上腕後部では有意な差が認められなかった。 上肢 の皮脂厚の年齢変化についてみると，上腕前部に 
表 4 肩甲骨下角部の皮脂厚値（性別・年齢別）

\begin{tabular}{|c|c|c|c|}
\hline $\begin{array}{l}\text { 年 龄 } \\
\text { (歳) }\end{array}$ & $\begin{array}{c}\text { 男 } \\
\text { 平均珄 } \\
\text { 標準偏差 (人数) }\end{array}$ & $\begin{array}{c}\text { 女性 } \\
\text { 平均値士標準偏差(人数) }\end{array}$ & $\mathrm{t}$ 值 \\
\hline & $\mathrm{mm}$ & $\mathrm{mm}$ & \\
\hline 新生児 & $3.1 \pm 0.6(83)$ & $3.1 \pm 0.6(88)$ & $(-0.62)$ \\
\hline 3 & $4.1 \pm 1.0(19)$ & $4.9 \pm 0.7(20)$ & $(-2.85)^{* *}$ \\
\hline 4 & $4.2 \pm 1.0(102)$ & $4.8 \pm 1.2(71)$ & $(-3.89)^{* * *}$ \\
\hline 5 & $4.0 \pm 1.0(114)$ & $4.7 \pm 1.1(101)$ & $(-5.50)^{* * *}$ \\
\hline 6 & $4.2 \pm 1.2(27)$ & $4.7 \pm 0.9(21)$ & $(-1.49)$ \\
\hline 15 & $5.6 \pm 1.5(59)$ & $-(-)$ & \\
\hline 19 & $-(-)$ & $6.7 \pm 1.5(26)$ & \\
\hline $20 \sim 29$ & $7.4 \pm 2.2(20)$ & $6.8 \pm 1.7(76)$ & \\
\hline $30 \sim 39$ & $7.5 \pm 1.9(60)$ & $7.8 \pm 2.2(89)$ & $(-0.76)$ \\
\hline $40 \sim 49$ & $7.6 \pm 2.2(82)$ & $8.1 \pm 2.0(133)$ & $(-1.74)$ \\
\hline $50 \sim 59$ & $7.1 \pm 2.0(108)$ & $8.2 \pm 2.6(157)$ & $-3.80^{* * *}$ \\
\hline $60 \sim 69$ & $7.3 \pm 2.4(75)$ & $8.3 \pm 3.1(90)$ & $-2.45^{*}$ \\
\hline 70歳以上 & $7.0 \pm 2.6(96)$ & $8.3 \pm 3.1(70)$ & $-2.88^{* *}$ \\
\hline
\end{tabular}

$\mathrm{t}$ 值: ${ }^{*} \mathrm{p}<0.05,{ }^{* *} \mathrm{p}<0.01,{ }^{* * *} \mathrm{p}<0.001, \mathrm{df}(\mathrm{n}-2)$ ，（）内は等分散.

表 5 腸骨稜上部の皮脂厚値（性別・年龄別）

\begin{tabular}{|c|c|c|c|}
\hline $\begin{array}{l}\text { 年 齢 } \\
\text { (歳) }\end{array}$ & $\begin{array}{c}\text { 男 } \quad \text { 性 } \\
\text { 平均値士標準偏差 (人数) }\end{array}$ & $\begin{array}{c}\text { 女 性 } \\
\text { 平均値士標準偏差(人数) }\end{array}$ & 値 \\
\hline 新生児 & $3.2 \pm 0.5(83)^{\mathrm{mm}}$ & $3.5 \pm 0.6(88)^{\mathrm{mm}}$ & $(-3.17)^{* *}$ \\
\hline 3 & $4.8 \pm 1.4(19)$ & $6.3 \pm 1.9(20)$ & $(-2.83)^{* *}$ \\
\hline 4 & $5.1 \pm 1.7(103)$ & $5.8 \pm 1.6(71)$ & $(-2.96)^{* *}$ \\
\hline 5 & $5.0 \pm 1.5(114)$ & $5.9 \pm 1.8(101)$ & $(-4.08)^{* * *}$ \\
\hline 6 & $4.8 \pm 2.0(27)$ & $5.9 \pm 1.9(21)$ & $(-2.10)^{*}$ \\
\hline 15 & $6.3 \pm 2.2(59)$ & $-(-)$ & \\
\hline 19 & $-(-)$ & $9.5 \pm 2.6(24)$ & \\
\hline $20 \sim 29$ & $10.9 \pm 3.5(19)$ & $10.7 \pm 3.9(74)$ & \\
\hline $30 \sim 39$ & $10.8 \pm 3.3(53)$ & $13.2 \pm 5.1(78)$ & $-3.32^{* *}$ \\
\hline $40 \sim 49$ & $11.7 \pm 3.8(66)$ & $14.7 \pm 5.4(106)$ & $-4.30^{* * *}$ \\
\hline $50 \sim 59$ & $9.7 \pm 3.9(83)$ & $15.4 \pm 6.8(140)$ & $-7.90^{* * *}$ \\
\hline $60 \sim 69$ & $9.3 \pm 3.2(72)$ & $14.3 \pm 5.7(89)$ & $-6.91^{* * *}$ \\
\hline 70歳以上 & $9.0 \pm 3.7(95)$ & $12.7 \pm 5.3(70)$ & $-5.05^{* * *}$ \\
\hline
\end{tabular}

$\mathrm{t}$ 值 : ${ }^{*} \mathrm{p}<0.05,{ }^{* *} \mathrm{p}<0.01,{ }^{* * *} \mathrm{p}<0.001, \mathrm{df}(\mathrm{n}-2)$ ，（）内は等分散。

おける最大値は男女とも12歳であり，成人女性の 皮脂厚は男性よりも幾分厚いながらも12歳览の值 よりも小さくなっている.上腕後部の皮脂厚では, 男性は 12 歳の $10.0 \mathrm{~mm}$ が最大であり,成年期の 5.9 $\mathrm{mm}$ が最小で，その值は 3 歳から 7 歳までの幼児 期の皮下脂肪の厚さよりもうすくなっている．こ れに対して，女性の場合は年龄が高くなるにつれ て皮下脂肪が厚くなり, 19歳・20歳代で $10.1 \mathrm{~mm}$ と いったん皮脂厚の值が小さくなるが，60歳代で
$12.3 \mathrm{~mm}$ と最大になっている。つまり，上腕後部 の皮下脂肪の厚さは 12 歳を分岐点に年齢が高くな るにつれ男性は減少傾向を，女性は増加傾向を示 すといった著しい違いがみられた。

2）体幹部の皮脂厚について

肩甲骨下角部，腸骨稜上部の皮脂厚の平均值及 び標準偏差は表 4 と表 5 である。これらの 2 部位 は, 計測上の都合で 7 歳児と 12 歳児のデーター収 集を行らことができなかった。また，対象者の検 
診時の脱衣状況が影響し，上肢部の標本数よりも 幾分少なくなっている。

肩甲骨下角部の皮下脂肪は 20 歳代を除いた全年 代に拈いて女性の方が男性よりも厚いが，性差が 認められたのは 3 歳, 4 歳, 5 歳, 50 歳以上であっ た. 年齢変化は, 男女とも 4 歳から 5 歳にかけて わずかに減少がみられるが，男性は40歳代で，女 性は60歳以上で最大となった。

腸骨稜上部の皮下脂肪は，新生児で既に性差が みられ，女性の方が男性よりも厚い。このうち， 20 歳代の皮脂厚の值は男女ともほぼ同じであった が，これは標本数の違いが影響している，年齢変 化では，男女とも 4 歳から 6 歳にかけてわずかに
増減がみられるがそれ以降は増加している。特に, 20歳を過ざると増加が顕著となり, 男性は 40 歳代 の $11.7 \mathrm{~mm}$ で，女性は50歳代の $15.4 \mathrm{~mm}$ で最大と なった。

\section{3）下肢の皮脂厚について}

下肢部の皮脂厚測定は体幹部よりもさらに時間 的制約があり，標本数も少ない，大腿前部(表 6) と大腿後部(表 7 ) とが20歳以下の年代で一部デー タ収集を可能にしたが，下腿後部（表 8 ）は成人 のみであった。

大腿前部，大腿後部，下腿後部のいずれの部位 の皮脂厚も，標本数の影響でばらつきがあるが， 全年代において皮下脂肪の厚さは女性の方が男性

表 6 大腿前部の皮脂厚值（性別・年齢別）

\begin{tabular}{|c|c|c|c|}
\hline $\begin{array}{l}\text { 年 齢 } \\
\text { (歳) }\end{array}$ & $\begin{array}{c}\text { 男 } \text { 性 } \\
\text { 平均値士標準偏差 (人数) }\end{array}$ & $\begin{array}{c}\text { 女性 } \\
\text { 平均值士標準偏差 (人数) }\end{array}$ & $\mathrm{t}$ 值 \\
\hline & $\mathrm{mm}$ & $\mathrm{mm}$ & \\
\hline 新生児 & $3.6 \pm 0.7(83)$ & $3.6 \pm 0.6(88)$ & $(0.81)$ \\
\hline 3 & $7.2 \pm 1.4(19)$ & $7.9 \pm 1.7(20)$ & $(-1.40)$ \\
\hline 4 & $6.5 \pm 1.4(103)$ & $7.9 \pm 1.7(71)$ & $(-5.70)^{* * *}$ \\
\hline 5 & $6.4 \pm 1.4(114)$ & $7.8 \pm 1.6(101)$ & $(-6.84)^{* * *}$ \\
\hline 6 & $6.5 \pm 1.4(27)$ & $8.0 \pm 2.0(21)$ & $(-3.28)^{* *}$ \\
\hline 19 & $-(-)$ & $13.2 \pm 2.8(24)$ & \\
\hline $20 \sim 29$ & $7.6 \pm 1.0(6)$ & $13.0 \pm 2.7(57)$ & \\
\hline $30 \sim 39$ & $8.9 \pm 1.4(4)$ & $14.6 \pm 3.9(12)$ & \\
\hline $40 \sim 49$ & $5.6 \pm 2.1(5)$ & $12.2 \pm 3.3(22)$ & \\
\hline $50 \sim 59$ & $6.5 \pm 2.5(18)$ & $12.6 \pm 5.6(35)$ & $-5.45^{* * *}$ \\
\hline $60 \sim 69$ & $8.1 \pm 2.8(41)$ & $13.1 \pm 4.9(41)$ & $-5.66^{* * *}$ \\
\hline 70 歳以上 & $7.0 \pm 2.8(75)$ & $14.7 \pm 5.5(41)$ & $-8.47^{* * *}$ \\
\hline
\end{tabular}

$\mathrm{t}$ 值: ${ }^{*} \mathrm{p}<0.05,{ }^{* *} \mathrm{p}<0.01,{ }^{* * *} \mathrm{p}<0.001, \mathrm{df}(\mathrm{n}-2),(\mathrm{)}$ 内は等分散.

表 7 大腿後部の皮脂厚值（性別・年齢別）

\begin{tabular}{|c|c|c|c|}
\hline $\begin{array}{l}\text { 年 齢 } \\
\text { (歳) }\end{array}$ & $\begin{array}{c}\text { 男 性 } \\
\text { 平均値士標準偏差 (人数) }\end{array}$ & $\begin{array}{c}\text { 女 性 } \\
\text { 平均值士標準偏差 (人数) }\end{array}$ & 值 \\
\hline & $\mathrm{mm}$ & $\mathrm{mm}$ & \\
\hline 4 & $5.9 \pm 1.2(9)$ & $7.0 \pm 1.4(7)$ & $(-1.58)$ \\
\hline 5 & $5.9 \pm 1.3(16)$ & $7.4 \pm 2.0(16)$ & $(-2.46)^{*}$ \\
\hline 6 & $6.5 \pm 1.3(6)$ & $12.0 \pm 2.3(24)$ & \\
\hline $20 \sim 29$ & $10.4 \pm 0.0(1)$ & $11.8 \pm 2.3(57)$ & \\
\hline $30 \sim 39$ & $8.8 \pm 3.0(4)$ & $14.7 \pm 5.9(12)$ & \\
\hline $40 \sim 49$ & $6.0 \pm 1.9(3)$ & $11.7 \pm 4.8(21)$ & \\
\hline $50 \sim 59$ & $8.0 \pm 2.9(12)$ & $13.0 \pm 6.6(29)$ & $-3.37^{* *}$ \\
\hline $60 \sim 69$ & $8.0 \pm 2.8(19)$ & $11.0 \pm 4.3(32)$ & $-3.08^{* *}$ \\
\hline 70歳以上 & $6.9 \pm 2.3(35)$ & $10.4 \pm 3.5(33)$ & $-4.87^{* * *}$ \\
\hline
\end{tabular}

$\mathrm{t}$ 值: ${ }^{*} \mathrm{p}<0.05,{ }^{* *} \mathrm{p}<0.01,{ }^{* * *} \mathrm{p}<0.001, \mathrm{df}(\mathrm{n}-2),(\quad)$ 内は等分散. 
よりも厚い、また，成年期に限ってみると，大腿 前部は各年齢での増減がみられるのに対して，大 腿後部と下腿後部は加齢とともに減少する傾向が ある。

\section{3.上肢と体幹との関係}

これまで，個別に皮脂厚の平均值を示してきた が，大きく分けて四肢と体幹とによって男女の差 ばかりでなく年齢的な意義もまた異なる。そこで，

表 8 下腿後部の皮脂厚值 (性別・年齢別)

\begin{tabular}{|c|c|c|c|}
\hline $\begin{array}{l}\text { 年 齢 } \\
\text { (歳) }\end{array}$ & $\begin{array}{c}\text { 男 性 } \\
\text { 平均值士標準偏差 (人数) }\end{array}$ & $\begin{array}{c}\text { 女 性 } \\
\text { 平均値士標準偏差 (人数) }\end{array}$ & 值 \\
\hline & $\mathrm{mm}$ & $\mathrm{mm}$ & \\
\hline $20 \sim 29$ & $5.8 \pm 1.4(6)$ & $7.4 \pm 0.0(1)$ & \\
\hline $30 \sim 39$ & $6.2 \pm 1.2(\quad 4)$ & $7.7 \pm 2.1(12)$ & \\
\hline $40 \sim 49$ & $3.9 \pm 1.4(5)$ & $5.9 \pm 1.5(22)$ & \\
\hline $50 \sim 59$ & $5.1 \pm 1.9(17)$ & $7.4 \pm 3.5(35)$ & $-3.01^{* *}$ \\
\hline $60 \sim 69$ & $4.7 \pm 1.3(41)$ & $6.3 \pm 2.1(41)$ & $-4.47^{* * *}$ \\
\hline 70 歳以上 & $4.8 \pm 1.7(74)$ & $6.8 \pm 2.2(41)$ & $-5.02^{* * *}$ \\
\hline
\end{tabular}

$\mathrm{t}$ 值: ${ }^{*} \mathrm{p}<0.05,{ }^{* *} \mathrm{p}<0.01,{ }^{* * *} \mathrm{p}<0.001, \mathrm{df}(\mathrm{n}-2),($ )内は等分散.

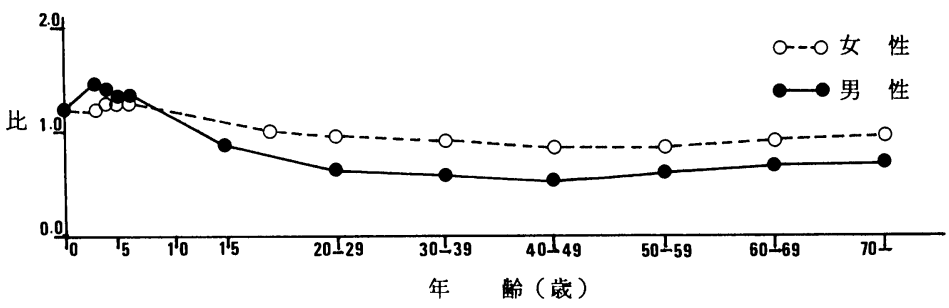

図 4 上肢と体幹との関係

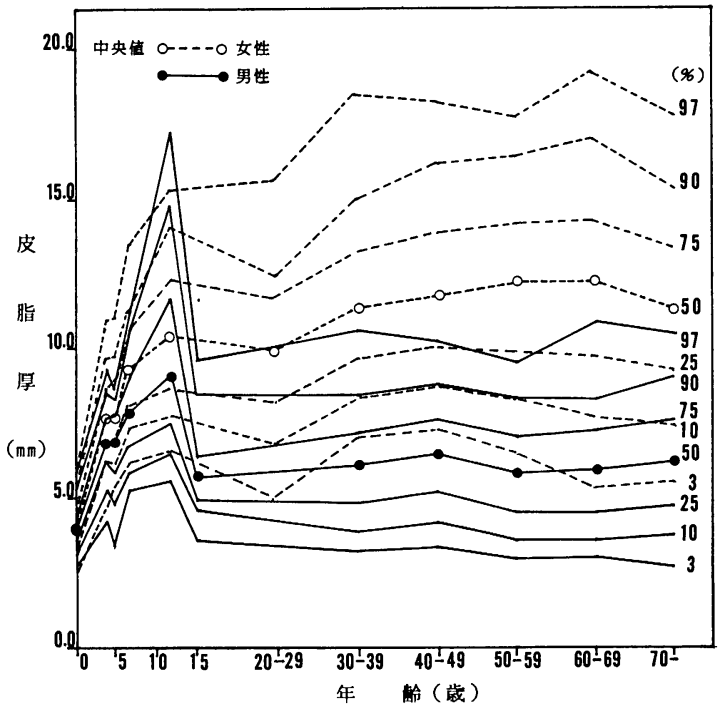

図 5 上腕後部のパーセンタイル値 (性別・年齢別皮脂厚値)

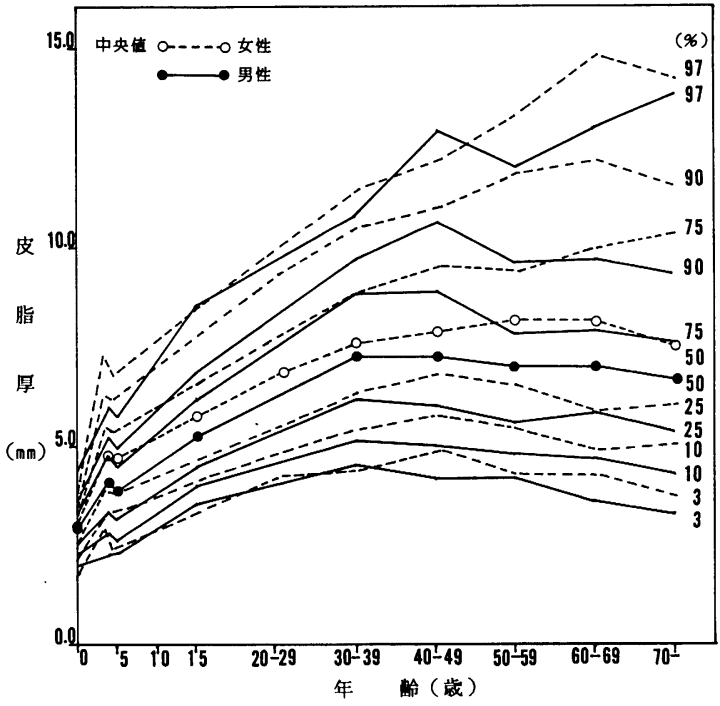

図 6 肩甲骨下角部のパーセンタイル值 (性別・年齢別皮脂厚値) 


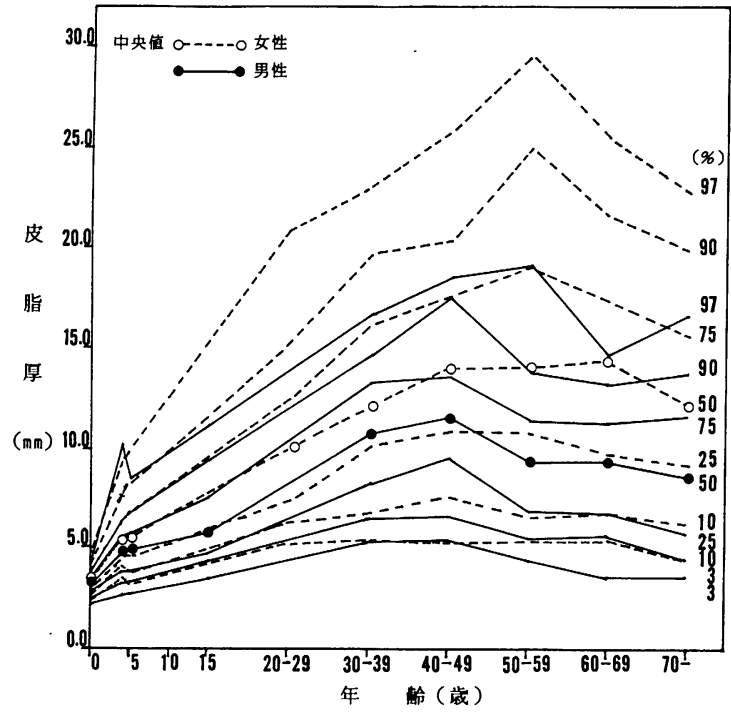

図7腸骨稜上部のパーセンタイル值 (性別・年齢別皮脂厚值)

上肢における上腕前部と上腕後部の皮脂厚の平均 值と，体幹に括ける肩甲骨下角部之腸骨稜上部の 皮脂厚の平均值を求め，この二つの值の年齢に伴 増減をみたのが図 4 である。これは上肢と体幹 との関係を対比的にみており，この比は，上肢の 皮脂厚值を体幹の皮脂厚值で除しているため， 1 の值よりも小さければその値は上肢よりも体幹に より多くの皮下脂肪が沈着していることを意味し ている，成年期では，男性が $0.5 \sim 0.7$ と女性の $0.8 \sim 1.1$ 值を下回り，男性は女性に比べて年齢 とともに体幹への肥厚が著しくなっていることを 示唆した.

\section{4. 皮脂厚のパーセンタイル值}

上腕後部，肩甲骨下角部，腸骨稜上部の 3 部位 の皮脂厚をそれぞれ男女別・年齢別にパーセンタ イル值であらわした，上腕後部は図 5 に，肩甲骨 下角部は図 6 に，腸骨稜上部は図 7 に示した。 50 パーセントにおける皮脂厚值即ち中央值を表 3 一表 5 で算出した算術平均値と比較すると，60歳 代の女性の上腕後部を除くいずれの部位について も，男女とも，そしてどの年齢においても，平均 值の方が中央値よりわずかに大きかった。 また， 平均值と中央值との差は, 12歳男児と70歳以上の
女性の上腕後部が $0.9 \mathrm{~mm}, 30$ 歳代および50歳代の 女性の腸骨稜上部が $1.0 \mathrm{~mm}$ と $1.3 \mathrm{~mm}$ であったの が最大であり，その他ではー0.3〜0.7mm の範囲 の差であったが，大部分では中央值の平均値とは ほぼ近い值であった。このうち，パーセンタイル 值による皮脂厚の分布の変化では, 上腕後部の 12 歳男児および腸管稜上部の50歳代女性では, 75 パーセント，90パーセント，97パーセントでの皮 脂厚の値が特に大きくなっていた。

\section{VI 考察}

1. Aモード式超音波皮脂厚計による計測の背 景と意義

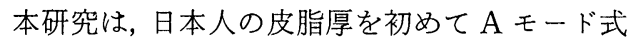
超音波皮脂厚計を用いて計測し，その性，年齢， 部位別分布を報告したものである。本研究で集計 した超音波皮脂厚值を国民栄養調査資料に記載さ れている栄研式皮脂厚計による皮脂厚值（栄研皮 脂厚値) と比較すると計測値自体は一致しないが, 性, 年齢, 部位別の分布について系統的にみると 栄研式, 超音波式のいずれも高年齢層汪ど皮脂厚 が増し，ある年龄（男女によって若干異なる）に 達すると減少するといら一連の傾向は符号する。 しかしながら，系統的にみた場合でも詳細に比較 すると皮脂厚が最大となる年齢は，比較できた部 位すなわち上腕後部と肩甲骨下角部では，栄研皮 脂厚值は男女ともいずれも40歳代であるのに対し $\tau$, 超音波皮脂厚值は上腕後部・肩甲骨下角部と も男性が40歳代で，女性が60歳代で最大值となる といった年龄差がある。しかも，栄研式による計 測によれば50歳以上の皮脂厚の減少度合がかなり 大きく, これに対して, 超音波式による計測值で は70歳代から減少しその減少量は栄研式の場合と はかなりくい違いがみられる。このことは，皮膚 の緊張度 (skin tone) に由来するためであり， Brožek•Kinzey（1960）は，20歳から69歳までの 男性の腕, 腹, 背中, ふくらはぎの 4 部位の計測 值が caliper の圧力 $\left(20 \mathrm{gm} / \mathrm{mm}^{2}, 10 \mathrm{gm} / \mathrm{mm}^{2}\right)$ に よって年齢的な変化の実験を行っでう, いわゆ る senile elastopsis (老人性線維症)のように皮虐 
にしわがよってたるんだ張りの無い者ほど皮下組 織の性状が圧力の影響を受けやすいので，それだ け老年者の皮脂厚の測定もまた困難であることを 指摘している。また，本研究の対象者の計測部位 は，上腕前部，上腕後部，肩甲骨下角部，腸骨稜 上部，大腿前部，大腿後部，下腿後部の 7 部位を 選定したが，下肢部の大腿前部と大腿後部は，従 来の skinfold caliperでは皮虚を挟みにくく，被 検者に苦痛を与えるため測定が難しいと言われて いた部位である。こうした皮脂厚計測に際しての 皮席の弾力性（skin tone）に起因する誤差につい ては, Himes et al（1979）は計測值を補正するこ とが必要であると述べているが，補正式や具体的 な補正値は示すに至っていない，超音波法による 皮脂厚值と skinfold caliper との比較について は, 豊川ら (1983a, 1983b) が比較検討を行って いる。 その結果, 猪口（1958）の屍体解剖による 直接法や, 弘島（1954）の生体（大腿部）を切開 して直接計測する場合と同様に, skinfold caliper と超音波法とでは一致せず超音波法による皮脂厚 值は skinfold caliper の絶対值の1.3 2.0倍で あった。さらには, 性, 年齢, 肥満度によっても 両法の計測值は異なることを認めた。このように， skinfold caliperによる計測值は検体要因によっ て複雑に変動するのである。そのうえ，計測者の クセと技能などの計測者要因も計測值を著しく変 動させるので, 超音波計測が確立するならば skinfold caliper に取ってかわることができるであろ 5 .

2. 標本の偏りと計測部位の限局について

$\mathrm{A}$ モード式超音波皮脂厚計の信頼性について は，大腿部に拈ける皮脂厚の計測值が超音波法と X 線 CT 法とで一致したこと(豊川ほか，1984b)， 測定者間の計測の検討では上腕部の皮脂厚值が最 も安定している（豊川ほか，1984c）, 計測技術の 熟練に伴って計測誤差が小さくなる（豊川ほか, 1985）などを明らかにしてきたが，さらには，B モード式超音波法との比較（石田ほか，1985）や， skinfold caliper との比較で計測者間および計測 者内誤差を求めること（Hatano et al，1987）に
よって精度の高さを確立してきた。しかし，本調 査の対象抽出は計画的に行われたものではなく偏 りがあることは否定しきれない，対象地区は，日 本全国のらちわずか 9 県にすぎず，しかもおもに 東京都周辺の地域に集中した。超音波皮脂厚計の 精度は skinfold caliper 法に勝るものとはい兄， 本報告の内容にも精度上の弱点がある，その原因 の大部分は対象（標本）の抽出の偏りに起因する. つまり, 本研究の対象者（標本）抽出は研究当初 から計画的に行われたものではなく，調査可能な 対象を逐次調査したものであるのでその偏りを否 定することはできない。しかし，対象者の身長及 び体重の平均値である限りでは，昭和58年度国民 栄養調査結果（厚生省，1985）の全国平均值と比 較して類似の值が得られたので著しい偏りのある 対象者であるとは言い切れない，皮脂厚值の標本 数については各部位とも一様ではなく限られた時 間内に比較的多い例数を計測したため，集団検診 に打いてみられるように計測項目を随時減らさな ければならなかった。しかしながら，本研究では 保健活動に打いて被検者に生じる圧迫感も少な く,かつ正常値を明らかにして欲しいという要望 の強い部位を計測しているので実用には問題な い、今後さらに調查を継続するにあたり，都道府 県全体から地域構造と対象者の職業など, 社会的 な背景を考慮にいれた系統的な標本抽出をおこな らことによって皮脂厚の分布に若干の変動がある かもしれないが，かなり大規模な標本調査を行わ ない限りこの種の誤差は解決できない。

\section{3. 既報資料との比較}

超音波式皮脂厚計による皮脂厚値の性・年齢別 の分布についての報告はほとんどない。唯一, Masser (1972) が 3 歳から14歳までの男女（男児 578名, 女児616名）について，上腕後部，肩甲骨 下角部，腸骨稜上部の 3 部位における皮脂厚を超 音波法で計測している。しかし，多くの研究者は 超音波法と他の計測法による皮脂厚值との比較の ために記載してあるのみで, 本研究の意図した内 容を盛り込んだ報告は現在のところ見当たらな い. 特に, わが国に扔いて本研究が最初の報告で 
ある.これに対し, skinfold caliperによる皮脂厚 の分布については数多くの文献が報告されてい る．日本では，公的資料として前述の国民栄養調 査があり，15歳以上の上腕後部，肩甲骨下角部の 2 部位の皮脂厚值が報告されている. Johnston et $\mathrm{al}$ (1974)の報告によれば，男児の上腕後部の皮下 脂肪の厚さのピークは11〜12歳であり，17歳で最 も減少している. 本研究の $\mathrm{A}$ モード式超音波皮脂 厚計による值もまた，男児の12歳に拉いてピーク が認められた。また， 3 歳から6 歳の男女にみら れる皮脂厚の増減もまた Masser (1972) の結果と 似ており，発育過程に拉ける伸長期及び活動期に 伴ら減少の一側面と考兄られる。ささらに，20歳代 の女性ではいずれの部位も皮脂厚の值が小さいこ とは，国民栄養調査や Johnston et al（1974）の 結果と一致しないが，保志（1984）は本研究と同 様の結果をみとめており，現代の若い女性が幾分 やせの傾向にあることを示している。

上肢と体幹との関係では，乳幼児期で体幹より も上肢に皮下脂肪が沈着し，ある時期をすぎると その関係は逆転し成人期において体幹が肥厚する 傾向は男女にみられ，特に男性にその傾向が強い。 これらの現象は，八木 (1930), Edwards (1950) が既に報告しており，50歳代の女性が体幹（中心 部）に皮下脂肪の沈着が最大となるのは閉経後の 婦人の特徵 (Edwards，1951）といえる。これは， 四肢（周囲）の皮下脂肪が減少し相対的に四肢よ りも体幹のほうが比が大きくなるものと考えられ る. Garn (1957)，Ashwell (1978) は女性の皮下 脂肪の分布を中心（体幹）に集をる “男性型” と 周囲（四肢）に分散する“女性型”に分けている。 これらの研究と本研究結果とを照合すると，女性 の大腿前位が男性よりも皮下脂肪が厚いことから も示㖫される。しかし，女性は皮下脂肪の量が男 性よりも多く, 皮脂厚による肥満度の判定は容易 であるが, Borkan et al（1982）が指摘するよう に, 男性は腹部の内臓周辺に脂肪が蓄積される夕 イプ，すなわち内藏脂肪型（垂井・松沢，1985） の肥満が多いので, 皮脂厚から体脂肪量の推定す るときは十分に注意する必要がある。

\section{VII ま と め}

本論文は, $\mathrm{A}$ モード式超音波皮脂厚計を用いて 得た日本人の性・年齢・部位別の皮下脂肪の代表 値に関する初めての全年齢階層にわたる報告であ り, 新生児から老人にいたる男女あわせて $3,410 人$ の上腕前部, 上腕後部, 肩甲骨下角部, 腸骨稜上 部, 大腿前部, 大腿後部, 下腿後部の 7 部位につ いて報告した。このうち, 下肢部の大腿前部と大 腿後部は，従来の skinfold caliper では皮膚を挟 みにくく，被検者に苦痛をあたえるため計測が難 しいために，ほとんど報告されていなかった。

性・年齢別の皮脂厚は女性の方が男性よりもす べての部位およびすべての年路で大きいこと, 上 腕後部では12歳以降に男女差が顕著になること, そして，体幹の肩甲骨下角部・腸骨稜上部の皮脂 厚值は，中高年齢層までは増加するが，ある年齢 に達すると減少することは, 在来の skinfold caliperによる報告を支持した。しかしながら, 詳 細に検討すると，超音波法の皮脂厚值は skinfold caliperのそれよりもやや大きめになること, 皮脂 厚が最大となるのが成人女性の上腕後部及び肩甲 骨下角部では skinfold caliper が40歳代なのに対 し, 超音波皮脂厚計では60歳代であるといった相 違があった。特に, 高年齢になるにつれて皮脂厚 の減少度合は, skinfold caliperの方が急激であ り,この違いが skinfold caliper の計測值が緊張 度 (skin tone) に影響されやすいことが容認され た。 また，新生児，幼児，少年の各期の経年変化 を，断面調查ではあるが，上肢と体幹の皮脂厚値 の関連性をみると，幼年期ではむしろ上肢に皮下 脂肪が厚く，成人期では上肢よりもむしろ体幹に 厚くなる。これは成人型の傾向として注目され， 20 歳以上の男女はともに上腕後部または大腿前部 よりも腸骨稜上部の方が皮下脂肪が多く，特に， 男性の方が女性よりも相対的に多いことが示され た。すなわち，男性では体幹の皮下脂肪の関与が 大きく，女性では四肢に皮下脂肪が多く分布する という性差を定量的に観察した。 


\section{文献}

Ashwell, M., Chinn, S., Stalley, S., Garrow, J.S. (1978): Female fat distribution-A photographic and cellularity study, Int. Journal Obesity, 2, 289-302

厚木 学 (1933): 日本人初生児/皮下脂肪分布二就 テ, 東京医学会雑誌, 47(9), 165一-198

Borkan, G.A., Gerzof, S.G., Robbins, A.H., Hults, D. E., Silbert, C.K., Silbert, J.E. (1982) : Assessment of abdominal fat content by computed tomography, Am. J. Clin. Nutr., 36, 172-177

Brožek, J., Kinzey, W. (1960): Age changes in skinfold compressibility, J. Gerontol, 15, 45-51

Edwards, D.A.W. (1950): Observations on the distribution of subcutaneous fat, Clin. Sci., 9, 259 $-270$

Edwards, D.A.W. (1951): Differences in the distribution of subcutaneous fat with sex and maturity, Clin. Sci., 10, 305-315

Garn, S.M. (1957) : Fat Weight and fat placement in the female, Science, 125, 1091-1092

Hatano, S., Fujita, T., Toyokawa, H., Kimura, N. (1987): Between- and with in-examiner variations in the measurement of subcutaneous fat using standard skinfold calipers and an A-mode type ultrasonic device, In Y. Yamori and C. Lenfant ed., Prevention of cardiovascular diseases: An aproach to active long life, 145-150, Elsevier Science Publishers V.V., (New York)

東定 (1954)：皮成㖪璧法による九州日本人生體 皮下脂肪の分布に関する研究. 第 1 編. 所謂皮局皺 譬法, 特にその計測誤差に就て, 熊本大学医学部解 剖学教室業績, 20,1-27

Himes, J.H., Roche, A.F., Siervogel, R.M. (1979): Compressibility of skinfolds and the measurement of subcutaneous fatness, Am. J. Clin. Nutr., $32,1734-1740$

弘島慶勝（1954）：生体に就いてのェーダー氏㱀譬法 による計測値と切開断面に於ける直接計測值との比 較に就いて, 遁信医学, 6(3), 193-195

保志 宏 (1984)：『日本人の体格調査報告書』から みた日本人の体格・体型所見, 人類学雑誌, 92(4), 281 $-293$

今井留香, 豊川裕之（1987）：早期新生児の皮下脂肪 厚，民族衛生，53(1)，14-37

猪口清一郎 (1958)：皮下脂肪厚計測法としての皮周 䐢譬法と直接法との関係, 解剖学雑誌, 33(2), 163 石田良恵, 角田直也, 金久博昭, 福永哲夫(1985)：超 音波皮脂厚計の検討，“体力科学，34(2), 91-97

Johnston, F.E., Hamill, P.V.V., Lemeshow, S.
(1974): Skinfold thickness of Youths 12-17 years United States, Vital and Health Statistics, $11,132,1-68$

Katch, F.I. (1983): Individual differences of ultrasound assessment of subcutaneous fat: Effects of body position, Human Biology, 55(4), 789-795

Keys, A., Brožek, J. (1953) : Body fat in adult man, Physiological reviews, 33(3), 245-325

厚生省保健医療局健康増進栄養課編（1985）：昭和60 年度国民栄養の現状。昭和58年国民栄養調查成績, 105-107, 第一出版社, (東京)

Masser, R. (1972): Die Ultraschallmessung der subcutanen Fettgewebsdicke zur Beurteilung des Ernährungszustandes von Kindern, Z. Kinderheilk, 112, 321-331

財団法人厚生統計協会（1984）：厚生の指標, 臨時増 刊，国民衛生の動向，31(9)，476-489，（東京）

垂井清一郎, 松沢佑次 編 (1985): 肥満一基礎と臨床 一，129－141，医薬ジャーナル社，（東京）

豊川裕之, 丸井英二, 木村信子, 高石昌弘(1983a)：集 団健診に拈ける超音波皮脂厚計と Skinfold caliper (栄研式, Harpenden 武)の計測値の比較, 第42回日 本公衆衛生学会総会講演集, 日本公衆衛生雑誌, 30 (11), 273

豊川裕之, 木村信子, 丸井英二, 河内まき子, 保志 宏 （1983b）：Skinfold caliper と超音波皮脂厚計の計 測值の比較, 第48回民族衛生学会総会講演集, 民族 衛生, 49, 256-257

豊川裕之, 木村信子, 佐伯圭一郎(1984a)：男子 66 名 (50～80歳)の18体部位の皮脂厚について, 第49回日 本民族衛生学会総会講演集, 民族衛生, 50, 168-169

豊川裕之, 木村信子, 丸井英二(1984b)：A-mode 式 超音波皮脂厚計の実用化のための基礎的研究（第1 報). 大腿部に扣ける標的波の同定の妥当性, 日本公 衆衛生雑誌, 31(1), 14-20

豊川裕之, 木村信子, 丸井英二 (1984c)：A-mode 式 超音波皮脂厚計の実用化のための基礎的研究. 上 腕・伸側部計測値の安定性, 民族衛生, 50(4), 197 $-204$

豊川裕之, 佐伯圭一郎, 木村信子, 今井留香, 西川浩 昭 (1985)： A モード武超音波皮脂厚計による計測 值の計測者間誤差, 第50回日本民族衛生学会総会講 演集，民族衛生，51，72-73

和才嘉昭, 沜田智明 (1975)：測定と評価, リハビリ テーション医学全畫 5,35 - 36 , 医歯薬出版株式会 社, (東京)

八木高次 (1930)：栄養標尺としての上膊囲の意義並 びにその規準について，其の二. 日本人に於ける皮 下脂熱の発育に就いて一日本人に対する Oeder 氏 脂熱法の批判一, 労働科学研究, 7(4), 649-741 